\title{
Teacher's electronic portfolio in professional standard of teacher
}

\author{
Irina S.Naydenova ${ }^{1, *}$ and Natalia N.Naydenova ${ }^{1}$ \\ ${ }^{1}$ ISED RAO, Centre of ComparativeEducation, 105062, Moscow, Russia
}

\begin{abstract}
Urgent questions related to the teacher professional standard, especially with the construction of its portfolio in electronic formis raised in the article. Today the most important indicator for the quality of teacher education is a professional competences of teachers which in demand with the era of postmodernism. However, attention is paid to such modern aspects of didactics as the digitization of learning and application of gadget technology in the educational process. The article analyzes the components, which today a teacher uses in the field of education and science of measuring the quality of social and emotional development of the student.
\end{abstract}

"In training and education, in all schoolaffairs nothingcan be improved, passing teacher's head" K.D. Ushinsky

\section{Introduction}

Promptly changing world makes all new and new demands to professional qualities of a teacher.

Requirements to professional competences of the teacher are developedin many countries including Russia,.In 2013, the decree of theRussianMinistry of Labourand Social Protection, claimed the professional standards of the teacher and now approbation of it is carried out.This law has to be realized on a mandatory basissince January $1,2017$.

The standard includes various characteristics of activity of a teacher, including competence: professional, object, measuring, evaluation, expertise, social-ethical and others [1].Thus, the professional standard of a teacher not only functions in a paradigm of knowledge, but also in other paradigms: social and moral (defines professional interaction), system and activity (expands borders of freedom of the teacher for professional activity), modernization (motivates to improve professional competences). In general introduction of such standard is necessary for education improvement of quality [2].

The professional portfolio can serve as reflection of development of professional competences of the teacher.Ability to make and form a portfolio is necessary from school age, but in order to teach the student, the teacher must first learn to shape their professional portfolio. It is possible to allocate several types of a portfolio:
- portfolio of achievements where the emphasis is placed on the received documents confirming continuous professional development in the course of professional activity;

- methodicalportfoliocontainingmethodological developments;

- a presentationportfolio helping as a rule at employment;

- thematicportfolio, the containing creative potential in activity of the teacher;

- portfoliodevelopmentis formedthroughout theeducational activities, recordedhis experiencesand progressin work;

- a complex portfolio that combine several types ofportfolio.

A teacher documentary evidence of his professional activitymust necessarily be includedin any kind of portfolio. It may be a paper and electronic versions [3, 4].In a century of information technologies an electronic portfolio becomes the visual business card of a teacher, representing all range of activity of a teacher and will help to present a complete picture of his professional self-determination, development and growth. Toformate any kind of a portfolio a teacher does a great job on systematization and generalization of the accumulated material [5].That is a teacher transformes from apractician to a researcher.

However, an electronic portfolio allows you to provide information more widely and more diverse, covering various aspects of their professional activities, and submitting your resume in a text clearer exemplary form with inclusion of social and emotional constructs.

It should be noted that the electronic portfolio - is not just collected documents and methodological developments in the electronic device (computer), as it could be understood only recently. This approach is

\footnotetext{
*orresponding author: irinasnaydenova@gmail.com
} 
outdated and has its limitations, such as the results of its activities can be demonstrated by a limited number of people (the administration of a particular pedagogical staff of educational institutions, parents). Now it is difficult to imagine life without the presence of the Internet and it gives great opportunities for teachers.

The electronic portfolio of the modern teacher is the website portfolio of the teacher. The huge audience of the interested people can see such electronic portfolio of achievements, use "successful" ideas, comment and estimate work of the teacher, his progress, there is an opportunity to discuss professional questions and to exchange experience

\section{The professional competence of a teacher in the context of postmodernism}

In recent decades, the changes in many areas of human life caused the necessity of philosophical reflection.Changing notions of cognitive activity, which is reflected directly in the activities of a teacher and should be reflected in the portfolio. Modern education is slowly being drawn into the modern trend in education philosophy - postmodernism [6]. The philosophy of postmodernism changes the angle of view: the subjectobject relations in the education process; acceptance of existence of a variety of teaching techniques; a change in trend in the formation of a knowledge transfer and reproduction by their pupils to create conditions for selfrealization of the child's potential; build individual learning path for each student; building a causal link in the implementation of informative activity of the student, etc. $[7 ; 8]$.

There are new requirements to competences of pedagogical staff. Behavioral training paradigm is increasingly replaced by critical. In any case, the critical elements of the paradigm of education are increasingly being introduced even in the practice of traditional education for the autochthonous paradigm [9].

Competences as the term are widely and actively used in a professional lexical turn as an indicator of professional skill of the teacher. In translation from Latin (competentia) this term designates presence at the person of the professional knowledge and abilities allowing solving professional problems and problems at an appropriate level.

The competent person - a person with expertise in the application of the professional competencies of a particular area, and competence - responsible and effective use of their professional skills. It has appropriate knowledge and abilities that allow it to act effectively in it [10].

Professional teacher standards define not only the core competencies, but also new competencies that allow you to develop an individual educational trajectory of each student, taking into account its capacity (psychological, emotional, physical) that is fully consistent with postmodernism [11]. Therefore besides requirements of subject competences and techniques of teaching, standard and legal and social and moral education for the solution of education tasks it is required to estimate objectively the level of education achievements, quality of training, in general quality of education in its complex, coherent and rizomorfny understanding[12].

It is also necessary to include in an electronic portfilio competences on: the development of test materials; application of modern theories and practices in test analysis; an expert on the test certification activities; development of new Public Quests evaluation methods; conduct various types of monitoring the quality of education in the classroom; taking into account age, gender and other characteristics; extracurricular activities; keeping an electronic diary, its own website; submission of online services for individual work with students; psycho-social and moral-emotional techniques; integration of knowledge from different sources and objects, and others.

One of the tools to assess the professional competence of a modern teacher is an e-portfolio. From the standpoint of the competency approach it is possible to reflect the whole spectrum of teacher pedagogical activity that allows interaction with other teachers on the development of professional competencies [13].

\section{Digitalization in teaching}

Many countries of the world, including Russia, puzzled by the process of introduction of digital technologies in the educational sphere.there is an actual discussion on electronic textbooks, and some schools replaced the paper textbook with an e-book readerrecently.

In addition information and communications technologyis activelyused, without which the present modern pedagogical process is difficult. A teacher begins to use electronic dictionaries, multimedia tutorials, interactive museums, etc.

Thus, we can talk about the beginning of digitalization in the learning process and the teacher need to keep up with times and be able to draw on the new technologies.At the Russian school a teacher from the first class uses digital technologies, and it helps to stimulate interest of a child in study.Hence there are high results in an international study among primary school graduates.

Use of electronic sources gives wider opportunities to a teacher and a pupil: minimum costs of information search, and fast processing, the analysis, an exchange, etc.,thus it is important both for the pupil and for the teacher.Constantly developing digital technologies require continuously improving ofteachers'professional skills in the field of modern information and communication technologies.

Thus the choice of the teacher for an electronic portfolio is obvious, and digital technologies will have a greater impact on the individual path of education for teachers and for teaching to individual path of education (training and development) of student, acquiring supranational traits [14]. 


\section{Implementation of gadget technologies}

Many of people are disturbed by a question of application of gadgets by modern children in everyday life. In many developed countries gadgets are introduced in teaching and educational process [15].

Often adults are disturbed by frequent use by children of tablets and smart phones.But the adults of various professions, including teachers, too, cannot imagine their life without electronic novelties, which modern realityoffers them.

This concern is not groundless, because the child usually uses gadgets for communication in social networks, games, and short learning to write their thoughts, supplementing them with bright pictures and making it more emotionally colored.

But there is a set of developing and training games bearing besides the entertaining functions, and education, dragging a child and motivating him to development, and the teacher's task to use actively such resources when training.E-book reader good alternative both of a modern child and of a teacher. Such book is similar to the tablet, it is possible to download in it several sources from which it is possible to choose, change reading settings that can too make reading process more attractive to a child. There is an opportunity to download additional education literature, reference books, works of art and so forth.

Using interactive whiteboard allows a teacher more colorful and accessible submit material reproduce the map from a necessary website, having increased scale, take a virtual tour of the past, and more.Unlike traditional individual work with pupils, distributing, for example, cards tasks that demands big time expenditure, using a gadget technology, a teacher can individualize work with pupils more effectively and to give everyone tasks of different level to send at a time to tablets of pupils personal tasks.

Competent use of technical innovations that kids love helps a teacher to be "on one wave" with the pupil. All used effective methods in gadget technology, and recommendations for their implementation or recommendations for the use of electronic resources for teacher gadgets can be placed in an e-portfolio, creating a special section that will undoubtedly be useful for teachers who want to improve their professional skills.

\section{Technology of emotional development}

Electronic Teacher portfolios must contain a section of diagnostic materials to assess students' knowledge. Of course, priority of schools and teachers is development of intellectual abilities of pupils. However, it is very difficultto achieve a desired resultwithout a positive emotional component, including an evaluation of educational achievements.

Emotional development is an essential component of the education concept that helps students acquire knowledge and skills for solving problems, to be successful and to quickly adapt to the changing conditions of the modern global world. Emotional skills and habits that were laid in childhood, becoming the foundation of a whole human future life therefore it is necessary to remember it working with children [16]. Every teacher can use a variety of methods for development of social and emotional sphere of students both in a classroom and in extracurricular activities, and even during a diagnostic work.

Teachers who perform work not automatically as robots, are interested in a child's development not only in cognitive aspect. Social and moral, spiritual and valuable, civil and ethnic and other aspects of development of the identity of the pupil join in measurement of quality of education as they reflect social and emotional intelligence which needs to be developed at school also, as well as cognitive abilities.

Therefore, training students adjust their emotions as one of sections of an electronic teacher's portfolio should be devoted to the techniques of emotional development. Studies of the American Committee for Children showed that young children with higher levels of empathy (the ability to empathize with others) tend to be less aggressive, more socially adapted and more successful in learning than children with low levels of empathy [17].

In addition to the acquisition of knowledge throughout life a child learns to recognize and manage their emotions, learning to care for others, to make decisions and take responsibility for them, learning to analyze and find a way out of difficult situations. Therefore, it is very important for a teacher to highlight and analyze its activity in this direction. And an electronic portfolio will allow the teacher to organize this work and follow dynamics.

For example, in the course of drawing up test works it is important to understand that the best result arises in the context of the supporting relations that allows to make test material interesting to a pupil and significant for all participants of education process. The text of a test has to bear emotional coloring, both in structure of supply of material, and in a possibility of estimation of level of social and emotional development of the pupil. In principle texts of tests have to be a social and humanitarian orientation and contain situations of the solution of problems of daily occurrence[18].

Important after performance of work to leave feeling of comfort and positive emotions at a child, then performance of the following work will cause a smaller stress, but does not feel like the loser [19].

Such section of an electronic portfolio can help teachers to find ideas for emotional development of pupils, increases of motivation to study, decrease in fear at children to examinations and tests [20].

\section{Conclusion}

The postmodern era requires new forms of professional activity and a change of the education processfrom teachers. A teacher was the "navigator" for a student in the world of knowledge. There is a shift from behaviorist paradigm of education to critical. Therefore, a teacher 
should not only give the knowledge and skills to teach but also help a student to become a competent person in a chosen subject and master competencies of social and emotional development, to become a full-fledged member of society in a classroom, school, home, community, country and the world.

Formation of a critical thinking little man is the task of the modern school. Teacher and student are equal partners in the educational process.

Digital technology is widely entered the modern world, in education, in everyday life. All these changes and professional activities of teachers, forcing him to keep up with the times and with his disciples.

The introduction of professional standards requiresthat every teacher has got modern portfolio and availability of electronic portfolio enhances its educational competence in various educational communities and networks.

Inclusion in portfolio of a teacher modern methods of training, upbringing of students with different gadgets displays teacher on an international level in the professional community. A gadget technology can not only improve reading competence of students, but also instill in them the need to work with a book, to impart him need of work with the book, to force them to pass to reading books of a different orientation.

So, paraphrasing an epigraph, one may say, that a modern electronic portfolio is that electronic prototype of everything that knows and competently uses a teacher, that is that "head.

\section{References}

1. Rossiiskaya Federatsiya, Ministerstvo truda iI sotsial'noi zashchity. Ob utverzhdeni professional'nogo standarta, Vestnik obrazovaniya Rossii J., 2, 10 ( 2014) [In Rus]

2. V.P. Veidt, Sovremennye problem nauki i obrazovaniya, 5, (2015). Available online: URL: http://www.science-

education.ru/ru/article/view? $\mathrm{id}=21770$ (accessed on: 08.03.2016).

3. S.A. Kopylova, Praktika administrativnoi raboty, 8 (2006) [In Rus]

4. B. Hannelore, Rodriguez-Farrar, Teaching Assistants and Teaching Fellows (The Harriet W. Sheridan Center for Teaching and Learning Brown University, 2006)

5. S. G. Paul, What Is Portfolio Assessment Really and How Can I Use It in My Classroom? (1995)

6. Yu. Narizhnyi, Filosofiya postmodernizma. Available online: URL: http://postmodern.in.ua/?p=1695 (accessed on 01.11.2014) [In Rus]

7. H. Giroux, Postmodernism, feminism, and cultural politics: redrawing Educational Boundaries (State University of New York Press, Albany, 1991).

8. G.A. Tsoi, Izvestiya Tomskogo politekhnicheskogo universiteta, Zhurnal, 6 (2010) [In Rus]
9. N.N. Naydenova, Materialy devyatoi mezhdunarodnoi nauchno-prakticheskoi konferentsii (VShE, Moskva, 2012) [In Rus]

10. Yu. G. Tatur, Vysshee obrazovanie segodnya, 3 (2004) [In Rus]

11. D.S. Rychen, and L.H. Salganik (Eds.) Defining and Selecting Key Competencies (2001)

12. N.N. Naydenova, Otechestvennaya I zarubezhnaya pedagogika, 1(2012) [In Rus]

13. R.N. Azarova, N.M. Zolotareva, Razrabotka pasporta kompetentsii (2010) [In Rus]

14. I.S.Naydenova, N.N. Naydenova, Innovatsii obrazovaniya, 12, 96 (2010) [In Rus]

15. Michael Quinion, Port Out, Starboard Home: The Fascinating Stories We Tell About the Words We Use (2004)

16. G.M. Breslav Psikhologiya emotsii, Smysl (Akademiya, Moskva, 2007) [In Rus]

17. J.A. Durlak, R.P. Weissberg, A.B. Dymnicki, R.D. Taylor, and K.B Schellinger, Journal CDEVC Child Development, January/February (2011)

18. W.L. Payne (1983/1986), Dissertation Abstracts International, 47, 203A (University microfilms No. AAC 8605928).

19. I.S. Naydenova, Pedagogicheskaya nauka: genezis i prognozy razvitiya. 2 (2014) [In Rus]

20. T.G. Novikova, M.A. Pinskaya, A.S. Prutchenkov, and E.E. Fedotova, Voprosy obrazovaniya, 3 (2004) [InRus] 